\title{
Uma outra maneira de estar
}

“A leitura é, provavelmente, uma outra maneira de estar em um lugar", eis Saramago com a agudeza dos que sabem ser precisos e profundos. Uma maneira bastante especial, diríamos em acordo com o escritor lusitano. Estar em estado de leitura implica considerar o livro em movimento, o leitor em fluxo de troca e de partilha com as palavras ditas e imaginadas e um encontro sempre imprevisível, já que nunca se sabe ao certo o que virá após a conclusão de uma obra ou de um texto. O fato é que, em se estando afetado pela leitura, já podemos falar em outra maneira de estar no mundo, outra janela de linguagem para apreciar a realidade. Tal assertiva indica o caminho que nos é caro ao pensarmos a Biblioteca Escolar: a leitura que nela pode ser inscrita, instalada e exercitada traz no bojo do seu nascedouro muitas consequências poéticas, políticas, estéticas e éticas.

Essa edição da Biblioteca Escolar em Revista passa a limpo algumas das questões envolvidas nessa trama da leitura no campo da unidade informacional escolar. O texto "A abordagem histórica na produção acadêmica sobre biblioteca escolar no brasil (2001-2012)", de Franciele Ruiz Pasquim, contribui para uma reflexão uma história da biblioteca escolar no Brasil, focalizando a partir de uma pesquisa documental e bibliográfica, os procedimentos de localização, recuperação, reunião, seleção e ordenação de fontes documentais no âmbito da biblioteca escolar.

Já o texto "Em defesa da biblioteca escolar: a prática baseada em evidências", das autoras Raquel da Silva Santos e Carla Erler Mattos Batista, apresenta o conceito de Prática Baseada em Evidências (PBE) como uma metodologia relevante para melhorar a prática profissional gerando evidências locais da influência da biblioteca escolar no aprendizado do aluno. O trabalho denominado "Letramento infantil na biblioteca escolar: desenvolvendo habilidades básicas para futuros leitores competentes", de Nádia Maria dos Santos Hommerding, apresenta um relato da experiência e aprendizado da autora atuando como bibliotecária no Sistema de Biblioteca Publicas de Miami Dade (MDPLS) em Miami, Estados Unidos. Sinaliza o papel estratégico da biblioteca escolar para desenvolvimento de habilidades de leitura em leitores na primeira infância.

De Douglas Guioroni Guaitorini Novelletto, William Barbosa Vianna e Moisés Lima Dutra, o texto "Gestão da Informação por meio físico e digital em Biblioteca Escolar: 
identificação de interesses dos usuários e tomada de decisão" identifica aspectos relevantes do acesso à informação de estudantes de uma Biblioteca Escolar Catarinense por meio físico e digital. O artigo "Bibliotecas Escolares e as Linguagens de Indexação", das autoras Vera Lucia Ribeiro Guim e Mariângela Spotti Lopes Fujita analisa as classificações nas bibliotecas escolares da rede pública municipal de ensino, constatando que as escolas apresentaram visões diferentes, segundo seu público usuário; o que sublinha a influência e representação das linguagens frente às instituições bem como seu propósito e importância. Os autores Eduardo Valadares da Silva e Silvana Ventorim apresentam o texto "A condição docente do bibliotecário escolar na educação básica", cujo tema é a função do bibliotecário escolar no contexto do debate sobre o trabalho e a condição docente por meio de uma pesquisa bibliográfica qualitativa.

Todos esses trabalhos estão em relação e sintonia, tecendo considerações sobre a leitura e os leitores no âmbito da biblioteca escolar como um espaço fecundo e potencializador de novas práticas de organização da informação e mediação e apropriação cultural. Está aqui o fio que nos enlaça e que nos move a acreditar mais e mais na biblioteca escolar como lócus de escuta dos modos de dizer e/ou silenciar os que se aproximam dos livros.

Claudio Marcondes de Castro Filho Lucília Maria Abrahão e Sousa Editores 